\title{
Rootstock Affects Floral Induction in Citrus Engaging the Expression of the FLOWERING LOCUS T (CiFT)
}

\author{
Stefania Bennici ${ }^{1,+}$, Giuseppina Las Casas ${ }^{1,+}$, Gaetano Distefano ${ }^{1, *}$, Alessandra Gentile ${ }^{1,2}$, Giuseppe Lana ${ }^{1}$ (D) \\ Mario Di Guardo ${ }^{1}$ (), Elisabetta Nicolosi ${ }^{1}{ }^{1}$, Stefano La Malfa ${ }^{1}$ and Alberto Continella ${ }^{1}$ \\ 1 Department of Agriculture, Food and Environment (Di3A), University of Catania, Via Valdisavoia 5, \\ 95123 Catania, Italy; stefania.bennici@hotmail.it (S.B.); giuseppina.lascasas@outlook.it (G.L.C.); \\ gentilea@unict.it (A.G.); giuseppe.lana51@gmail.com (G.L.); mario.diguardo@unict.it (M.D.G.); \\ enicolo@unict.it (E.N.); slamalfa@unict.it (S.L.M.); acontine@unict.it (A.C.) \\ 2 College of Horticulture and Landscape, Hunan Agricultural University, Changsha 410128, China \\ * Correspondence: gaetano.distefano@unict.it \\ + These authors contributed equally to this work.
}

Citation: Bennici, S.; Las Casas, G.; Distefano, G.; Gentile, A.; Lana, G.; Di Guardo, M.; Nicolosi, E.; La Malfa, S.; Continella, A. Rootstock Affects Floral Induction in Citrus Engaging the Expression of the FLOWERING LOCUS T (CiFT). Agriculture 2021, 11, 140. https://doi.org/10.3390/ agriculture 11020140

Academic Editor: Manuel Jamilena Received: 12 January 2021

Accepted: 5 February 2021

Published: 8 February 2021

Publisher's Note: MDPI stays neutral with regard to jurisdictional claims in published maps and institutional affiliations.

Copyright: (C) 2021 by the authors. Licensee MDPI, Basel, Switzerland. This article is an open access article distributed under the terms and conditions of the Creative Commons Attribution (CC BY) license (https:// creativecommons.org/licenses/by/ $4.0 /)$.

\begin{abstract}
In Citrus, flower induction represents the transition from vegetative to reproductive growth. The regulation of flower induction is mainly triggered by exposure to low temperatures and waterdeficit stress, which activates the signaling cascade leading to an increased expression of the citrus orthologs of the FLOWERING LOCUS T (CiFT). In this study, the relationship between rootstock and flower induction under Mediterranean field conditions was investigated by monitoring the expression levels of the floral promoter CiFT2 in leaves of the pigmented sweet orange "Tarocco Scirè" grafted onto "C 35 " citrange and "Swingle" citrumelo rootstocks. The latter two are known to confer, respectively, high and low yield efficiency to the scion. In both rootstock/scion combinations, CiFT2 showed a seasonal expression with a peak during the inductive period in January triggered by cold temperature. The "Tarocco Scirè" /"C35" citrange combination showed the highest expression levels for CiFT2; this increased expression was correlated with yield and a higher number of flowers in the following spring, suggesting a significant effect of rootstocks on flower induction mediated by the overexpression of the CiFT2 gene.
\end{abstract}

Keywords: reproductive biology; endogenous factor; gene expression; "C35" citrange; "Swingle" citrumelo; Citrus sinensis (L.) Osb

\section{Introduction}

Sweet orange is one of the most important fruit crops in the world in terms of both production and harvested area: in 2018, the annual world production was equal to $75,413,374$ tons with a corresponding harvested area of 4,469,719 hectares [1]. The most important countries in terms of production were Brazil, China and India $(22 \%, 12 \%$ and $11 \%$ of the total production; [1]). Sweet orange cultivation strongly characterizes many Mediterranean countries. The Mediterranean countries with the highest production of sweet orange are Spain and Italy with 3.6 and 1.5 million tons, respectively [1]. Sweet orange is particularly prized for its fruit quality, especially for the organoleptic properties as well as for the nutraceutical value of the fruit (e.g., high content in antioxidant molecules and vitamins).

In Citrus, the reproductive phase occurs after a long juvenile period (approximately 6 years) during which the flower development is inhibited [2]. At maturity, citrus plants do not show a true dormancy; this reflects their original nature as tropical-subtropical evergreen species [3]. Furthermore, several works have indicated that floral induction in citrus occurs independently of the photoperiod [4]. Low temperatures $\left(10-18{ }^{\circ} \mathrm{C}\right.$ day $/ 5-13{ }^{\circ} \mathrm{C}$ night) and water-deficit stress are recognized as the main factors involved in the induction of flowering in citrus [4-7]. 
In recent years, several studies have been carried out to elucidate the mechanisms and the complex network of genes underlying florigen signaling [8]. In Arabidopsis, several flowering-related genes have been characterized [9-11], and further sequence homology studies evidenced that such genes are highly conserved in many other species, including citrus [12]. Among these genes, the citrus FLOWERING LOCUS T homologs (CiFTs) showed a close correlation with floral induction [13] as demonstrated by transformation studies highlighting the correlation between early flowering and the overexpression of the CiFTs in Citrus species such as trifoliate orange (Poncirus trifoliata L. Raf) and sweet orange [14-16].

At first, three CiFTs were characterized in Satsuma mandarin using a cloning approach: CiFT1, CiFT2 and CiFT3. All three CiFTs showed a putative function in flowering induction [17]. Then, the availability of the reference genome of $C$. clementine (http:/ / www.phytozome.org/, accessed on 22 January 2020) allowed a finer characterization of such transcripts, revealing that CiFT1 and CiFT2 were indeed alleles of the same gene (Ciclev10013731m) renamed CiFT1; meanwhile, CiFT3 was encoded by a different gene (Ciclev10012905m) renamed CiFT2 [18]. In the same work, Samach detected a third CiFT homolog gene (Ciclev10012629m) named CiFT3. Among these CiFTs homologs, CiFT2 was the only gene expressed during the flower inductive period in citrus. Transcriptomic studies performed on different Citrus species (i.e., mandarins, sweet orange, pummelo) highlighted the interplay between CiFT2 endogenous expression and the floral inductive signals $[17,19-21]$. In short, the inductive signals are perceived in leaves triggering the expression of the FT gene, and then the product of the FT gene, florigen, moves by the phloem to the shoot apical meristem inducing the flowering response via the activation of meristem identity genes such as LEAFY (LFY) and APETALA1 (AP1) [22-25]. In this model, an important role in influencing CiFT2 expressions is played by environmental factors such as cold temperature and water-deficit stress. Exposure to both stimuli, low temperature and water-deficit stress, has been associated with an increase in expression levels of CiFT2 in sweet orange and Satsuma mandarin $[17,20,21]$.

Although the environmental stimuli described above certainly play a key role in controlling citrus flowering, there is much evidence suggesting that the flowering response to inductive conditions could also be influenced by endogenous factors such as fruit load, nutritional status and hormonal balance. In citrus, the flowering inhibition is strictly related to juvenility and alternate bearing with direct repercussions on the productive volumes. Alternate bearing mainly results from suppression of flowering by heavy fruit production and late harvest, determining a reduction in the flower number (thus the number of fruits on the tree) in the following year [26]. In citrus, the high fruit load during the floral inductive period (affecting flowering in the following spring) is correlated with a reduction in the expression levels of the CiFT2 gene [27,28]. Low flowering intensity, determined by high fruit load, is often accompanied by a nitrogen shortage in leaves [29]. Several works have reported the active role of the hormone balance in modulating changes in CiFT gene expression. Exogenous applications of gibberellins (GAs) in citrus during the flower bud induction period inhibit flowering by repressing CiFT expression in buds and leaves [30,31]. In contrast, endogenous accumulation of abscisic acid (ABA) in mandarin shoots during the floral induction period under low temperatures $\left(15^{\circ} \mathrm{C}\right)$ was correlated with the accumulation of CiFT transcripts and eventually with flowering intensity [32].

While several studies are available on the effect of the above-mentioned factors on flower induction, few reports have focused on the role of other factors such as the choice of the rootstock, even though it is well known that hormonal signaling is strictly related to rootstock-scion communication [33].

This aspect is of particular interest for many crops, including all Citrus species, which are routinely grafted since the choice of the rootstock can greatly influence traits of economic interest such as plant architecture, yield, fruit quality and tolerance to biotic and abiotic stress [34]. It has already been demonstrated in other perennial fruit tree crops (apple, mango and avocado) that flowering can be influenced by different factors including 
rootstock $[35,36]$. Similar studies were conducted in sweet cherry and pear, in which it was observed that rootstock affects the scion precocity, the abundance of flowering and the attitude of flowers to set fruit [37]. For centuries, the cultivation of sweet orange relied on the application of grafting; in the Mediterranean area, in particular, the most widely used rootstock was sour orange (C. aurantium L.). The reasons behind the wide use of sour orange relied on its positive influence on fruit yield and on its wide adaptability to different environmental conditions and the tolerance to many biotic diseases. Unfortunately, the high susceptibility to Citrus Tristeza Virus (CTV) hampers its use in new plantings [38]. To overcome this problem, citranges (C. sinensis (L.) Osb. x Poncirus trifoliata (L.) Raf.) and other intergeneric hybrids (i.e., "Swingle" citrumelo) tolerant to CTV have been used [39]. However, CTV-tolerant rootstocks cannot be safely employed in all environments since they suffer from specific limitations due to either abiotic or biotic stress. In light of this, the development of novel rootstocks and their evaluation in different environments is still an essential step for the development of novel genotypes able to both adapt to different environmental conditions and to confer optimal fruit quality characteristics to the fruit [40-43]. Beside this, the evaluation of potential rootstocks must also consider their agronomic performance in combination with different scions. Recently, the fruit quality and yield of the pigmented sweet orange variety "Tarocco Scirè" grafted onto nine different rootstocks showing CTV tolerance were evaluated over several years. Even though "C 35 " citrange and "Swingle" citrumelo were characterized by similar canopy volume, the former registered the highest cumulative yield among the rootstocks tested while "Swingle" citrumelo was characterized by one of the lowest productions [39].

The effect of the rootstock on the flowering intensity suggests that the choice of the rootstock could greatly influence the expression levels of CiFT genes, with direct repercussions on flowering and fruiting intensity. To test this hypothesis, the expression patterns of the CiFT2 gene were evaluated in the leaves of "Tarocco Scirè" sweet orange grafted onto "C35" citrange (TS/C35) and "Swingle" citrumelo (TS/SC) to investigate their correlation with the flower bud induction period in relation to the temperature regimes, and the correspondence between the CiFT2 expression and the flowering intensity and fruit load.

\section{Materials and Methods}

\subsection{Plant Material}

The study was performed on 7-year-old "Tarocco Scirè" pigmented sweet orange (C. sinensis (L.) Osb.) trees grafted onto two rootstocks, "C35" citrange (C. sinensis (L.) Osb. $\times$ Poncirus trifoliata (L.) Raf.) (TS/C35) and "Swingle" citrumelo (C. paradisi Macf. $\times$ Poncirus trifoliata (L.) Raf.) (TS/SC) growing in the experimental field of Lentini (Siracusa province, south Italy, $37^{\circ} 17^{\prime} 04^{\prime \prime} \mathrm{N}, 14^{\circ} 53^{\prime} 16^{\prime \prime} \mathrm{E}$; at an altitude of approximately $57 \mathrm{~m}$ above sea level). Trees were planted $5 \times 3 \mathrm{~m}$ apart and drip-irrigated, fertilized and grown according to standard cultural practices.

\subsection{Harvest Data and Sampling}

Four trees with similar canopy volume were used for each rootstock/scion combination (TS/C35 and TS/SC). Twenty-eight fully developed mature leaves per thesis were collected from non-fruiting branches monthly from September 2017 to July 2018. For each rootstock/scion combination, the collected leaves were quickly frozen in liquid nitrogen and stored at $-80^{\circ} \mathrm{C}$ until RNA extractions performed in three replicates. The flowering intensity was evaluated in spring (April 2018) by selecting three branches per tree with similar size and having an equal number of nodes (approximately 300 ). The branches were chosen from different sides of the tree at about $2 \mathrm{~m}$ above the soil level. The number of flowers per sprout was counted and expressed as the number of flowers per 100 nodes to normalize the differences in the size of the selected branches. Fruits were harvested at commercial maturity in March in both years of assessment (2018 and 2019). The yield was evaluated at harvest during the seasons $2017 / 2018$ and 2018/2019 by measuring the fruit 
weight and the number of harvested fruits per tree. Temperature data during the sampling period were provided by the Servizio Informativo Agrometeorologico Siciliano (SIAS) (http:/ / www.sias.regione.sicilia.it/, accessed on 25 January 2020).

\subsection{Total RNA Extraction and $c D N A$ Synthesis}

Total RNA was extracted from frozen leaves using Spectrum ${ }^{\mathrm{TM}}$ Plant Total RNA Kit (Sigma-Aldrich, Saint Louis, USA) and treated with DNase I (On-Column DNase I Digestion Set, Sigma-Aldrich, Saint Louis, USA) following the protocol described by Distefano et al. [44]. RNA concentration and purity were assessed by the $\mathrm{OD}_{260} / \mathrm{OD}_{280}$ ratio using a spectrophotometer (NanoDrop-2000, Thermo Scientific, USA), while RNA integrity was verified by $1 \%$ agarose gel electrophoresis. cDNA was synthesized from $1 \mu \mathrm{g}$ of total RNA using the High Capacity cDNA Reverse Transcription Kit (Applied Biosystems, Waltham, USA) according to the procedure indicated by the manufacturer.

\subsection{Real Time-PCR}

The Real Time-PCR (RT-PCR) assays were performed on the Rotor-Gene $Q$ thermocycler (Qiagen, Hilden, Germany) in $20 \mu \mathrm{L}$ total reaction volume containing $1 \times$ PCR buffer II, $2 \mathrm{mM} \mathrm{MgCl} 2,0.2 \mathrm{mM}$ dNTPs, $0.3 \mu \mathrm{M}$ of forward and reverse primer (Eurofins Genomics), $1.5 \mu \mathrm{M}$ SYTO9 (Life Technologies, UK), $50 \mathrm{ng}$ of the synthesized cDNA and 1U of MyTaq DNA polymerase (Bioline, UK). The CiFT2 was amplified using the following primers reported by Nishikawa et al. [17]: 5'-CAACAAAATTTCATCACTTGAATAGTC-3' and $5^{\prime}$-AAACACTCAACAACACTTAGCACAAA-3'. The housekeeping gene used for relative quantification of CiFT2 abundance was citrus Elongation Factor 1-alpha (EF-1 $\alpha$, accession AY498567) [45] amplified using the following primers: 5'-ATTGACAAGCGTGTGATTGAGC-3' and $5^{\prime}$-TCCACAAGGCAATATCAATGGTA- $3^{\prime}$.

Thermal cycling conditions included an initial denaturation at $95{ }^{\circ} \mathrm{C}$ for $5 \mathrm{~min}$, followed by 35 cycles at $95^{\circ} \mathrm{C}$ for $5 \mathrm{~s}, 58^{\circ} \mathrm{C}$ for $20 \mathrm{~s}$ and $72{ }^{\circ} \mathrm{C}$ for $2 \mathrm{~min}$. The threshold cycle $\left(\mathrm{C}_{\mathrm{T}}\right)$ values were used to calculate the expression level of CiFT2 relative to EF-1 $\alpha$ transcript using the Rotor-Gene Q software (v2.1.0).

\subsection{Statistical Analysis}

The graphs and the statistical analysis ( $t$-test and ANOVA) were performed using the "stat" package of the R software [46]. The ANOVA test was employed to detect significant differences among more than two groups ( $p$-values $<0.05$ ); post-hoc Tukey test was then applied to detect which pairwise comparison showed significant differences (adjusted $p$-value $<0.05) . T$-test was applied to test differences in means among two groups of observations.

\section{Results}

In this study, the effect of rootstock on flower induction was investigated through the assessment of CiFT2 expression in leaves of "Tarocco Scirè" sweet orange grafted onto "C35" citrange and "Swingle" citrumelo, two rootstocks characterized by high and low yield efficiency, respectively. The mRNA expression levels were monitored from September 2017 to July 2018, and results were then correlated with temperature trends, flowering intensity and yield production.

Seasonal changes were observed in the expression levels of CiFT2 throughout the experimental period (Figure 1). From September to December 2017, the CiFT2 expression remained relatively low, and then both combinations showed an increase in January 2018 (with TS/C35 showing a significantly higher CiFT2 expression compared with TS/SC). From February to the spring season 2018 (June), the expression level remained low in both combinations with a second peak registered in July 2018 (Figure 1). 


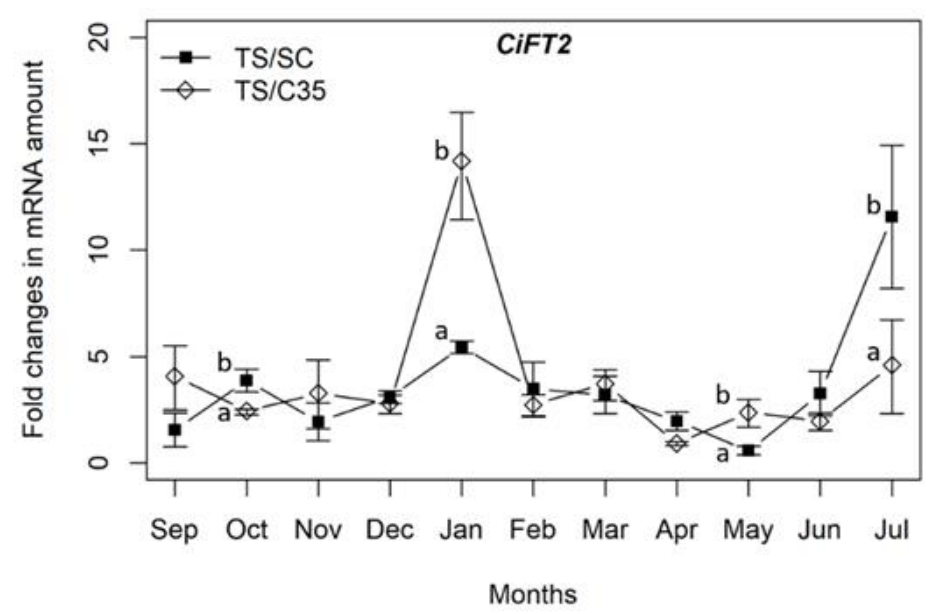

Figure 1. Changes in CiFT2 expression levels in leaves of "Tarocco Scirè" scion grafted onto "C35" citrange (TS/C35) and "Swingle" citrumelo (TS/SC) rootstocks from September 2017 to July 2018. Each value is the mean of three technical replicates \pm standard deviation. Different letters for the same sampling date indicate significant difference between rootstocks using Student's $t$-test $(p$-value $<0.05)$.

Even though both rootstock/scion combinations showed an increased CiFT2 expression during the inductive period (January 2018), the expression level in TS/C35 was three-fold higher than TS/SC ( $p$-value $=0.02$ ) (Figure 1). A significant difference in gene expression between the two rootstock/scion combinations was also observed in July $(p$-value $=0.04)$ and October $2018(p$-value $=0.03)$; in both cases the expression level of CiFT2 was significantly higher in TS/SC, whilst in May 2018 a significantly higher expression $(p$-value $=0.03)$ was recorded in TS/C35 (Figure 1).

The average maximum and minimum temperatures $\left({ }^{\circ} \mathrm{C}\right)$ registered throughout the experimental period are shown in Figure 2. The temperatures showed a marked decrease in autumn, reaching the minimum value $\left(5.0^{\circ} \mathrm{C}\right)$ in December 2017 (Figure 2); then, temperatures began to increase throughout the spring season reaching their highest maximum value $\left(35.4^{\circ} \mathrm{C}\right)$ in July 2018 (Figure 2$)$.

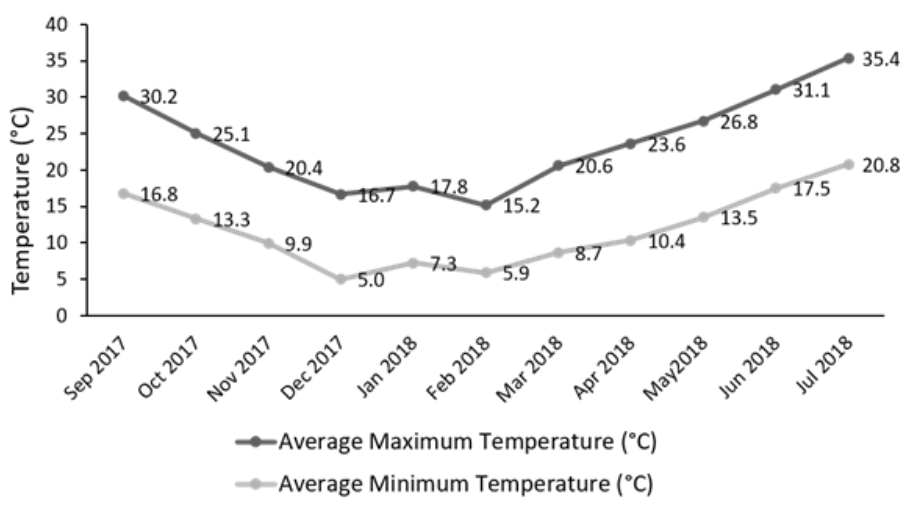

Figure 2. Average maximum and minimum temperature $\left({ }^{\circ} \mathrm{C}\right)$ registered during the sampling period (source SIAS; http:/ / www.sias.regione.sicilia.it/, accessed on 25 January 2020).

The flowering intensity was estimated in spring (April 2018) by counting the number of flowers per 100 nodes (Figure 3). Results revealed significant differences among the two rootstock/scion combinations, with TS/C35 showing the highest number of flowers compared with TS/SC $(p$-value $=0.01)$. 


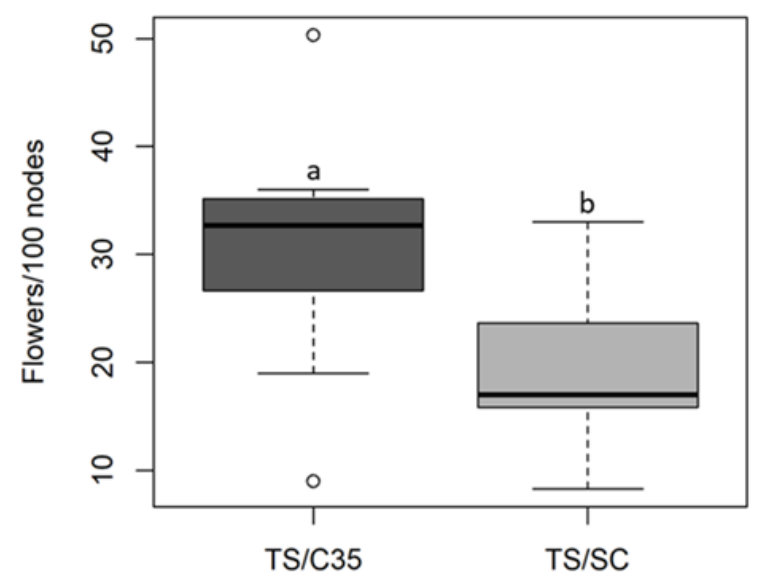

Figure 3. Number of flowers per 100 nodes recorded on "Tarocco Scirè" scion grafted onto "C35" citrange (TS/SC, dark gray box) and "Swingle" citrumelo (TS/SC, light gray box) rootstocks in April 2018. Each value is the mean of four trees per rootstock. Different letters indicate significant difference between rootstocks ( $p$-value $<0.05)$.

The fruit yield (resulting from the blooming of the previous year) was evaluated at harvest in two consequent years in 2018 and 2019 (Figure 4a,b). In both years, TS/C35 showed both the highest fruit production (Figure $4 \mathrm{a}, p$-value $=0.00$ in 2018 and $p$-value $=0.01$ in 2019) and highest number of fruits (Figure $4 b, p$-value $=0.00$ in 2018) compared with TS/SC; in the latter case no significant difference was shown in 2019 (Figure $4 b, p$-value $=0.37$ ).
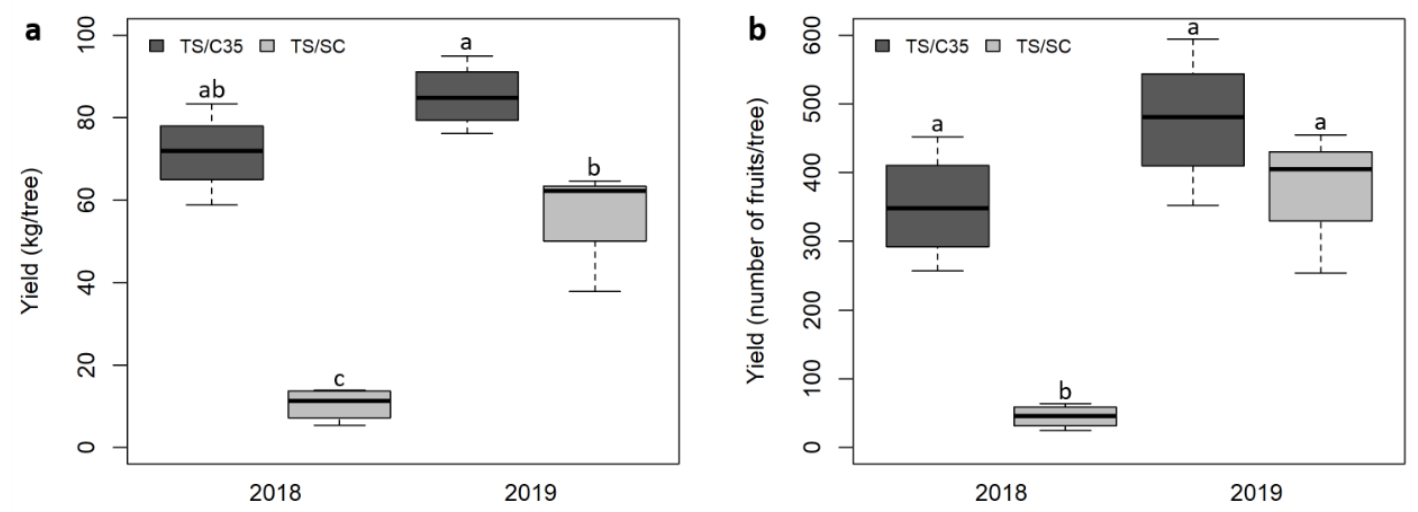

Figure 4. Yield expressed as $\mathrm{kg} /$ tree (a) and number of fruits/tree (b) recorded on "Tarocco Scirè" scion grafted onto "C35" citrange (TS/C35, dark gray boxes) and "Swingle" citrumelo (TS/SC, light gray boxes) for two subsequent years: 2018 (blooming 2017) and 2019 (blooming 2018). Each value is the mean of four trees per rootstock. Different letters indicate significant difference between rootstocks using ANOVA test followed by Tukey post-hoc test (adjusted $p$-value $<0.05$ ).

\section{Discussion}

Flowering induction is regulated by a complex interaction of environmental factors and endogenous genetic regulation systems [47]. In recent years, several studies have been carried out to unravel the mechanisms of florigen signaling in plants, elucidating the complex genetic network involved in the regulation of flowering [8]. In Citrus, low temperatures $\left(15-20^{\circ} \mathrm{C}\right)$ and water-deficit stress are recognized as the main factors involved in the induction of flowering [21,48]. Likewise, the flowering response could also be influenced by endogenous factors such as fruit load [27,28], altered nutritional and carbohydrate metabolism, or increased levels of gibberellin (GA) [30,49] and abscisic acid (ABA) [32].

In this study, the effect of rootstock on flower induction was investigated through the analysis of CiFT2 expression in leaves of "Tarocco Scirè" sweet orange, grafted onto two rootstocks: "C35" citrange and "Swingle" citrumelo, characterized by a marked difference 
in yield [39]. The expression of this gene was monitored from September 2017 to July 2018 and correlated with temperature trends, flowering intensity and yield production.

Previous reports have highlighted the tight connection between temperatures and flower-gene expression: an increased expression of CiFT genes during the transition from winter to spring was observed in Satsuma, suggesting a strong association between CiFT expression levels and floral induction triggered by low temperature $[17,50,51]$. Similarly in "Washington" navel orange, low-temperature treatments promoted flowering by increasing the expression of CiFT in leaves [19,20].

Temperatures registered during the experimental period (Figure 2) showed a marked decrease in autumn, reaching their lowest value $\left(5^{\circ} \mathrm{C}\right)$ in December 2017, just before the increase in CiFT2 expression levels, suggesting a direct effect of low temperature on the flower induction and the expression levels of CiFT2.

This phenomenon is particularly evident for TS/C35, while the CiFT2 expression levels detected on TS/SC reached the maximum in July; such increased expression is not reported in Satsuma mandarin, in which floral induction and expression of CiFTs occurred only during early winter (in accordance with what was detected for TS/C35) [51]. The increase in expression levels of CiFT2, observed in TS/SC from May to July (when flowering is finished and the temperature has increased), could be linked to the interplay between endogenous and other environmental factors rather than temperature. In kumquat and trifoliate orange, an increase in the expression levels of CiFT2 was observed during early summer, during (or just before) the onset of the flower organs [48]. Similar results were observed in pummelo (C. grandis Osbeck) and "Pineapple" sweet orange by Pajon et al. [52], suggesting that the increase in CiFT gene expression soon after flowering is probably associated with changes in light conditions or internal signal regulation. Other factors could have played a role in the high expression levels recorded in July for TS/SC; among these are the increased solar radiation availability and the water-deficit stress induced by the very high evaporative demand during summer, even in irrigated plants. Both high levels of solar radiation and water-deficit stress have been demonstrated to exert an effect on the expression of CiFT transcripts in sweet orange by Chica and Albrigo [20,21].

It has been reported that CiFT expression during floral induction in citrus trees is closely correlated with the number of flowers in the following spring [53,54]. This is further confirmed by our analysis in which TS/C35 plants showed a significantly higher flowering intensity compared with TS/SC ( $p$-value $=0.0163$, Figure 3 ), supporting the hypothesis that rootstock affects floral induction in sweet orange by regulating the expression pattern of CiFT2.

Among the factors involved in flowering, fruit load is known to act as a repressive stimulus $[27,28,55]$ for the CiFT2 expression in the following year. To test this assumption, fruit yield was evaluated at harvest in 2018 and 2019 (Figure 4a,b). In both years, TS/C35 had a higher yield than TS/SC (Figure 4a,b). Interestingly, the low fruit yield in TS/SC measured in March 2018 was not associated with an increased expression level of CiFT2 during the inductive period (January 2018), and similarly, the higher production of TS/C35 in March 2018 did not act as a repressive stimulus for the CiFT2 expression in January 2018.

This result indicates that the relation between fruit load and CiFT2 expression could be actively influenced by the rootstock through complex mechanisms (which are still largely unclear).

Rootstock controls many of the physiological aspects of the scion through the regulation of the gene expression in the scion. For example, it has been reported that the superoxide dismutase (SOD) activity in the leaves of the lemon cv. "Verna" grafted onto C. macrophylla or C. reticulata rootstocks was mainly influenced by the rootstock rather than by the different salt concentrations tested [56]. Jensen et al. [57] observed significant differences in the expression of genes potentially involved in photosynthesis, tree size, stress tolerance and flowering of the apple cultivar "Gala" grafted onto dwarfing and semi-dwarfing rootstocks. In particular, "Gala" grafted onto the dwarfing rootstock showed higher expression of several genes related to photosynthesis and cell division, 
while plants grafted onto the semi-dwarfing one showed increased stress-related gene expression. Prassinos et al. [58] used cDNA-AFLP and microarray approaches to examine the gene expression in multiple tissues from sweet cherry "Bing" scions on dwarfing and semi-dwarfing rootstocks. Results revealed a differential expression of several transcription factors and genes in the scion and in the graft union.

The short- and long-distance transport of mRNA, small RNA and proteins from the rootstock to the scion has been reported, but little is known on how these molecules can modulate important phenotypic traits in the scion [34]. Several studies have speculated on the possibility that FT proteins or m-RNAs are able to move across a graft junction affecting flowering in the scion [59]. This hypothesis was demonstrated in tomato, Arabidopsis and cucurbits [25,60-62]. In Jatropha, the use of transgenic rootstocks overexpressing FT genes determined early flowering in the scion [63]. In apple, RNA sequencing indicated that flowering genes including FT-like genes (MdFT1 and MdFT2) are upregulated in the vascular tissue of dwarfing rootstocks and are responsible for the early flowering of the scion [35]. No information about the translocation of FT products from rootstock to scion has been reported for citrus; however, different citrus rootstocks significantly affect the expression of genes involved in auxin signal transduction and GA biosynthesis pathways in grafted mandarins [64]. The role of GAs in the control of flowering in citrus by the regulation of CiFT expression in leaves is known [30,31]. Tang and Lovatt [65] suggested that floral inhibition in "Washington" navel orange, caused by $\mathrm{GA}_{3}$ application, is independent of $F T$ expression in buds; however, the possibility that $\mathrm{GA}_{3}$ regulates floral induction through FT cannot be excluded. This hypothesis is also confirmed by Collani et al. [66] who evidenced the role of the bZIP transcription factor FD (known to interact with $F T$ at the shoot) in the regulation of GA metabolism. Recently, it was observed that transgenic Carrizo rootstock lines expressing the C. clementina FT gene under the control of the Arabidopsis thaliana phloem-specific SUCROSE SYNTHASE 2 (AtSUC2) promoter induce precocious flowering in non-transgenic "Valencia" scion [67]. The analysis of FT gene expression in non-transgenic scion leaves grafted onto FT transgenic rootstocks showed an increase of two-fold higher compared with shoots emerging from non-transgenic rootstocks at the fully open flower stage [67]. These results suggest an important role of rootstocks in the control of flowering by regulation of $F T$ gene expression in the scion.

\section{Conclusions}

In citrus, environmental factors such as low temperature and water-deficit stress as well as endogenous factors, including fruit load, nutritional status and hormonal metabolism, regulate flower induction by the expression of CiFT2. It is known that rootstock controls many aspects of vegetative vigor and fruit yield in the scion; however, its effects on flower induction in the scion have been investigated less. Our results showed that rootstocks affect floral induction in sweet orange and that this effect is mediated by the regulation of CiFT2 expression in scion leaves during the inductive period. Under our conditions (Mediterranean climate), a higher expression level for CiFT2 was recorded in TS/C35 as compared with TS/SC, associated with an increased flowering intensity in the following spring. Interestingly, this expression pattern was independent of the fruit yield level, suggesting that complex mechanisms underlying the rootstock effect in modulating different physiological behavior are still unclear. The interaction between rootstock and cultivar seems to play a key role to enhance genetic expression involved in flowering induction. The overall results provide insights into the regulation of flower induction in citrus, which could guide the choice of rootstocks combining fruit crop yield and quality.

Author Contributions: Conceptualization, S.B. and G.D.; validation, S.B. and G.L.C.; formal analysis, S.B., G.L.C. and G.L.; resources, A.G.; data curation, M.D.G.; writing—original draft preparation, S.B. and G.L.C.; writing-review and editing, G.D., A.G., M.D.G. and S.L.M.; supervision, E.N., A.G., A.C. and S.L.M.; project administration, A.G.; funding acquisition, A.G. All authors have read and agreed to the published version of the manuscript. 
Funding: This research was funded by the Ministero dell'Istruzione dell'Università e della Ricerca-Project PRIN “Investigating Self-Incompatibility DEterminants in fruit trees (ISIDE)” Prot. 2015BPM9H3.

Institutional Review Board Statement: Not applicable.

Informed Consent Statement: Not applicable.

Data Availability Statement: The data presented in this study are available on request from the corresponding author.

Conflicts of Interest: The authors declare no conflict of interest.

\section{References}

1. FAO. Available online: http:/ / faostat.fao.org/default.aspx (accessed on 30 April 2018).

2. Goldschmidt, E.; Monselise, S. Hormonal control of flowering in citrus trees and other woody perennials. In PlantGrowth Substances; Carr, D.J., Ed.; Springer: Berlin/Heidelberg, Germany, 1972; pp. 758-766.

3. Spiegel-Roy, P.; Goldschmidt, E.E. Biology of Citrus; Cambridge University Press: New York, NY, USA, 1996.

4. Moss, G.I. Influence of temperature and photoperiod on flower induction and inflorescence development in sweet orange (Citrus sinensis L. Osbeck). Hortic. Res. 1969, 44, 311-320.

5. Cassin, J.; Bourdeuet, J.; Fougue, A.; Furon, V.; Gailland, J.; Bourdelles, P.; Montaguad, G.; Moreuil, C. The influence of climate upon the blooming of citrus in tropical areas. Proc. First Int. Citrus Symp. 1969, 1, 315-323.

6. Garcia-Luis, A.; Kanduser, M.; Santamarina, P.; Guardiola, J.L. Low temperature influence on flowering in Citrus. The separation of inductive and bud dormancy releasing factors. Physiol. Plant. 1992, 86, 648-652. [CrossRef]

7. Southwick, S.M.; Davenport, T.L. Characterization of water stress and low temperature effects on flower induction in Citrus. Plant. Physiol. 1986, 81, 26-29. [CrossRef] [PubMed]

8. Khan, M.R.G.; Ai, X.-Y.; Zhang, J.-Z. Genetic regulation of flowering time in annual and perennial. WIREs RNA 2014, 5, 347-359. [CrossRef] [PubMed]

9. Komeda, Y. Genetic regulation of time to flower in Arabidopsis thaliana. Annu. Rev. Plant. Biol. 2004, 55, 521-535. [CrossRef] [PubMed]

10. Albani, M.C.; Coupland, G. Comparative analysis of flowering in annual and perennial plants. Curr. Top. Dev. Biol. 2010, 91, 323-348. [CrossRef]

11. Pin, P.A.; Ove, N. The multifaceted roles of FLOWERING LOCUS T in plant development. Plant. Cell Environ. 2012, 35, 1742-1755. [CrossRef]

12. Dornelas, M.; Camargo, R.; Figueiredo, L.; Takita, M. A genetic framework for flowering-time pathways in Citrus spp. Genet. Mol. Biol. 2007, 30, 769-779. [CrossRef]

13. Velázquez, K.; Agüero, J.; Vives, M.; Aleza, P.; Pina, J.; Moreno, P.; Navarro, L.; Guerri, J. Precocious flowering of juvenile citrus induced by a viral vector based on Citrus leaf blotch virus: A new tool for genetics and breeding. Plant. Biotechnol. J. 2016, 14, 1976-1985. [CrossRef]

14. Endo, T.; Shimada, T.; Fujii, H.; Kobayashi, Y.; Araki, T.; Omura, M. Ectopic expression of an FT homolog from Citrus confers an early flowering phenotype on trifoliate orange (Poncirus trifoliata L. Raf.). Transgenic Res. 2005, 14, 703-712. [CrossRef]

15. Nishikawa, F.; Endo, T.; Shimada, T.; Fujii, H.; Shimizu, T.; Kobayashi, Y.; Araki, T.; Omura, M. Transcriptional changes in CiFT-introduced transgenic trifoliate orange (Poncirus trifoliata L. Raf.). Tree Physiol. 2010, 30, 431-439. [CrossRef] [PubMed]

16. Pons, E.; Alquézar, B.; Rodríguez, A.; Martorell, P.; Genovés, S.; Ramón, D.; Zacarías, L.; Peña, L. Metabolic engineering of $\beta$-carotene in orange fruit increases its in vivo antioxidant properties. Plant. Biotechnol. J. 2014, 12, 17-27. [CrossRef]

17. Nishikawa, F.; Endo, T.; Shimada, T.; Fujii, H.; Shimizu, T.; Omura, M.; Ikoma, Y. Increased CiFT abundance in the stem correlates with floral induction by low temperature in Satsuma mandarin (Citrus unshiu Marc.). J. Exp. Bot. 2007, 58, 3915-3927. [CrossRef] [PubMed]

18. Samach, A. Congratulations, you have been carefully chosen to represent an important developmental regulator! Ann. Bot. 2013, 111, 329-333. [CrossRef]

19. Pillitteri, L.J. Isolation and Characterization of a TERMINAL FLOWER Homolog and Its Correlation with Juvenility in Citrus. Plant. Physiol. 2004, 135, 1540-1551. [CrossRef] [PubMed]

20. Chica, E.; Albrigo, L. Changes in CsFT Transcript Abundance at the Onset of Low-temperature Floral Induction in Sweet Orange. J. Am. Soc. Hortic. Sci. 2013, 138, 184-189. [CrossRef]

21. Chica, E.; Albrigo, L. Expression of flower promoting genes in sweet orange during floral inductive water deficits. J. Am. Soc. Hortic. Sci. 2013, 138, 88-94. [CrossRef]

22. Abe, M.; Kobayashi, Y.; Yamamoto, S.; Daimon, Y.; Yamaguchi, A.; Ikeda, Y.; Ichinoki, H.; Notaguchi, M.; Goto, K.; Araki, T. FD, a bZIP protein mediating signals from the floral pathway integrator FT at the shoot apex. Science 2005, 309, 1052-1056. [CrossRef]

23. Huang, T.; Böhlenius, H.; Eriksson, S.; Parcy, F.; Nilsson, O. The mRNA of the arabidopsis gene FT moves from leaf to shoot apex and induces flowering. Science 2005, 309, 1694-1696. [CrossRef]

24. Wigge, P.; Kim, M.; Jaeger, K.; Busch, W.; Schmid, M.; Lohmann, J.; Weigel, D. Integration of spatial and temporal information during floral induction in Arabidopsis. Science 2005, 309, 1056-1059. [CrossRef] 
25. Corbesier, L.; Vincent, C.; Jang, S.; Fornara, F.; Fan, Q.; Searle, I.; Giakountis, A.; Farrona, S.; Gissot, L.; Turnbull, C.; et al. FT protein movement contributes to long-distance signaling in floral induction of Arabidopsis. Science 2007, 316, 1030-1033. [CrossRef]

26. Moss, G.I. Effect of fruit on flowering in relation to biennial bearing in sweet orange (Citrus sinensis). Hortic. Sci. 1971, 46, 177-184. [CrossRef]

27. Muñoz-Fambuena, N.; Mesejo, C.; Carmen González-Mas, M.; Primo-Millo, E.; Agustí, M.; Iglesias, D.J. Fruit regulates seasonal expression of flowering genes in alternate-bearing "Moncada" mandarin. Ann. Bot. 2011, 108, 511-519. [CrossRef]

28. Shalom, L.; Samuels, S.; Zur, N.; Shlizerman, L.; Zemach, H.; Weissberg, M. Alternate bearing in Citrus: Changes in the expression of flowering control genes and in global gene expression in ON- versus OFF-crop trees. PLoS ONE 2012, 7, e46930. [CrossRef] [PubMed]

29. Martínez Fuentes, A.; Mesejo, C.; Reig, C.; Agustí, M. Timing of the inhibitory effect of fruit on return bloom of 'Valencia' sweet orange Citrus sinensis (L.) Osbeck). J. Sci. Food Agric. 2010, 90, 1936-1943. [CrossRef] [PubMed]

30. Muñoz-Fambuena, N.; Mesejo, C.; González-Mas, M.; Iglesias, D.; Primo-Millo, E.; Agustí, M. Gibberellic acid reduces flowering intensity in sweet orange [Citrus sinensis (L.) Osbeck] by repressing CiFT gene expression. J. Plant. Growth Regul. 2012, 31, 529-536. [CrossRef]

31. Goldberg-Moeller, R.; Shalom, L.; Shlizerman, L.; Samuels, S.; Zur, N.; Ophir, R.; Blumwald, E.; Adka, A. Effects of gibberellin treatment during flowering induction period on global gene expression and the transcription of flowering-control genes in Citrus buds. Plant. Sci. 2013, 198, 46-57. [CrossRef] [PubMed]

32. Endo, T.; Shimada, T.; Nakata, Y.; Fujii, H.; Matsumoto, H.; Nakajima, N.; Ikoma, Y.; Omura, M. Abscisic acid affects expression of citrus FT homologs upon floral induction by low temperature in Satsuma mandarin (Citrus unshiu Marc.). Tree Physiol. 2017, 38, 755-771. [CrossRef] [PubMed]

33. Aloni, B.; Cohen, R.; Karni, L.; Aktas, H.; Edelstein, M. Hormonal signaling in rootstock—scion interactions. Sci. Hortic. 2010, 127, 119-126. [CrossRef]

34. Koepke, T.; Dhingra, A. Rootstock scion somatogenetic interactions in perennial composite plants. Plant. Cell Rep. 2013, 32, 1321-1337. [CrossRef]

35. Foster, T.M.; Watson, A.E.; Van Hooijdonk, B.M.; Schaffer, R.J. Key flowering genes including FT-like genes are upregulated in the vasculature of apple dwarfing rootstocks. Tree Genet. Genomes 2014, 10, 189-202. [CrossRef]

36. Sharma, N.; Kumar, S.; Kumar, A.; Ravishankar, H.; Dubey, A.K.; Kumar, N. Physiological and molecular basis of alternate bearing in perennial fruit crops. Sci. Hortic. 2019, 243, 214-225. [CrossRef]

37. Webster, A.D. Rootstock and interstock effects on deciduous fruit tree vigour, precocity, and yield productivity. N. Z. J. Crop. Hortic. Sci. 2010, 23, 373-382. [CrossRef]

38. Moreno, P.; Ambrós, S.; Albiach-Martí, M.R.; Guerri, J.; Peña, L. Citrus tristeza virus: A pathogen that changed the course of the citrus industry. Mol. Plant. Pathol. 2008, 9, 251-268. [CrossRef]

39. Continella, A.; Pannitteri, C.; Malfa, S.L.; Legua, P.; Distefano, G.; Nicolosi, E.; Gentile, A. Influence of different rootstocks on yield precocity and fruit quality of 'Tarocco Scirè' pigmented sweet orange. Sci. Hortic. 2018, 230, 62-67. [CrossRef]

40. Louzada, E.; del Rio, H.; Setamou, M.; Watson, J.; Swietlik, D. Evaluation of citrus rootstocks for the high pH, calcareous soils of South Texas. Euphytica 2008, 164, 13-18. [CrossRef]

41. Reforgiato-Recupero, G.; Russo, G.; Recupero, S.; Zurru, R.; Deidda, B.; Mulas, M. Horticultural Evaluation of New Citrus latipes Hybrids as Rootstocks for Citrus. HortScience 2009, 44, 595-598. [CrossRef]

42. Legua, P.; Forner, J.; Hernández, F.; Forner-giner, M. Total phenolics, organic acids, sugars and antioxidant activity of mandarin (Citrus clementina Hort. ex Tan.): Variation from rootstock rootstock. Sci. Hortic. 2014, 174, 60-64. [CrossRef]

43. Fu, S.; Shao, J.; Zhou, C.; Hartung, J.S. Transcriptome analysis of sweet orange trees infected with 'Candidatus Liberibacter asiaticus' and two strains of Citrus Tristeza Virus. BMC Genom. 2016, 17, 1-18. [CrossRef]

44. Distefano, G.; Cirilli, M.; Las Casas, G.; La Malfa, S.; Continella, A.; Rugini, E.; Thomas, B.; Long, G.; Gentile, A.; Muleo, R. Ectopic expression of Arabidopsis phytochrome B in Troyer citrange affects photosynthesis and plant morphology. Sci. Hortic. 2013, 159, 1-7. [CrossRef]

45. Distefano, G.; Caruso, M.; La Malfa, S.; Gentile, A.; Tribulato, E. Histological and molecular analysis of pollen-pistil interaction in clementine. Plant. Cell Rep. 2009, 28, 1439-1451. [CrossRef] [PubMed]

46. R Core Team R: A Language and Environment for Statistical Computing; R Foundation for Statistical Computing: Vienna, Austria, 2017.

47. Amasino, R. Seasonal and developmental timing of flowering. Plant. J. 2010, 61, 1001-1013. [CrossRef] [PubMed]

48. Nishikawa, F. Regulation of floral induction in Citrus. J. Jpn. Soc. Hortic. 2013, 82, 283-292. [CrossRef]

49. Martínez-Fuentes, A.; Mesejo, C.; Juan, M.; Almela, V.; Agustí, M. Restrictions on the exogenous control of flowering in Citrus. Acta Hortic. 2004, 632, 91-98. [CrossRef]

50. Inoue, H. Effects of soil drought and temperature on flower bud differentiation of satsuma mandarin. J. Jpn. Soc. Hortic. Sci. 1989, 58, 581-585. [CrossRef]

51. Nishikawa, F.; Endo, T.; Shimada, T.; Fujii, H.; Shimizu, T.; Omura, M. Differences in seasonal expression of flowering genes between deciduous trifoliate orange and evergreen satsuma mandarin. Tree Physiol. 2009, 29, 921-926. [CrossRef] [PubMed]

52. Pajon, M.; Febres, V.J.; Moore, G.A. Expression patterns of flowering genes in leaves of "Pineapple" sweet orange [Citrus sinensis (L.) Osbeck] and pummelo (Citrus grandis Osbeck). BMC Plant. Biol. 2017, 17, 1-7. [CrossRef] 
53. Nishikawa, F.; Iwasaki, M.; Fukamachi, H.; Nonaka, K.; Imai, A.; Takishita, F.; Yano, T.; Endo, T. Fruit bearing suppresses citrus FLOWERING LOCUS T expression in vegetative shoots of satsuma mandarin (Citrus unshiu Marc.). J. Jpn. Soc. Hortic. Sci. 2012, 81, 48-53. [CrossRef]

54. Nishikawa, F.; Iwasaki, M.; Fukamachi, H.; Endo, T. Predicting the number of flowers in Satsuma Mandarin (Citrus unshiu Marc.) trees based on Citrus FLOWERING LOCUS T mRNA levels. Hortic. J. 2017, 86, 305-310. [CrossRef]

55. Agustí, M.; Mesejo, C.; Muñoz-Fambuena, N.; Vera-Sirera, F.; de Lucas, M.; Martinez-Fuentes, A.; Reig, C.; Iglesias, D.J.; Primo-Millo, E.; Miguel, A. Fruit-dependent epigenetic regulation of flowering in Citrus. New Phytol. 2019. [CrossRef]

56. Almansa, M.; Hernandez, J.; Jimenez, A.; Botella, M.; Sevilla, F. Effect of salt stress on the superoxide dismutase activity in leaves of Citrus limonum in different rootstock-scion combinations. Biol. Plant. 2002, 45, 545-549. [CrossRef]

57. Jensen, P.; Rytter, J.; Detwiler, E.; Travis, J.; McNellis, T. Rootstock effects on gene expression patterns in apple tree scions. Plant. Mol. Biol. 2003, 53, 493-511. [CrossRef]

58. Prassinos, C.; Ko, J.; Lang, G.; Iezzoni, A.; Han, K. Rootstock-induced dwarfing in cherries is caused by differential cessation of terminal meristem growth and is triggered by rootstock-specific gene regulation. Tree Physiol. 2009, 29, 927-936. [CrossRef]

59. Putterill, J.; Varkonyi-Gasic, E. FT and florigen long-distance flowering control in plants. Curr. Opin. Plant. Biol. 2016, 33, 77-82. [CrossRef] [PubMed]

60. Lifschitz, E.; Eviatar, T.; Rozman, A.; Shalit, A.; Goldshmidt, A.; Amsellem, Z.; Alvarez, J.; Eshed, Y. The tomato FT ortholog triggers systemic signals that regulate growth and flowering and substitute for diverse environmental stimuli. Proc. Natl. Acad. Sci. USA 2006, 103, 6398-6403. [CrossRef]

61. Lin, M.-K.; Belanger, H.; Lee, Y.-J.; Varkonyi-Gasic, E.; Taoka, K.-I.; Miura, E.; Xoconostle-Cázares, B.; Gendler, K.; Jorgensen, R.A.; Phinney, B.; et al. FLOWERING LOCUS T protein may act as the long-distance florigenic signal in the cucurbits. Plant. Cell Online 2007, 19, 1488-1506. [CrossRef]

62. Notaguchi, M.; Abe, M.; Kimura, T.; Daimon, Y.; Kobayashi, T.; Yamaguchi, A.; Tomita, Y.; Dohi, K.; Mori, M.; Araki, T. Longdistance, grafttransmissible action of Arabidopsis FLOWERING LOCUS T protein to promote flowering. Plant. Cell Physiol. 2008, 49, 1645-1658. [CrossRef]

63. Ye, J.; Geng, Y.; Zhang, B.; Mao, H.; Qu, J.; Chua, N.-H. The Jatropha FT ortholog is a systemic signal regulating growth and flowering time. Biotechnol. Biofuels 2014, 7, 1-11. [CrossRef]

64. Liu, X.; Li, J.; Liu, M.; Yao, Q.; Chen, J. Transcriptome Profiling to Understand the Effect of Citrus Rootstocks on the Growth of 'Shatangju' Mandarin. PLoS ONE 2017, 2013, 1-22. [CrossRef] [PubMed]

65. Tang, L.; Lovatt, C.J. Effects of low temperature and gibberellic acid on floral gene expression and floral determinacy in ‘Washington 'navel orange (Citrus sinensis L. Osbeck). Sci. Hortic. 2019, 243, 92-100. [CrossRef]

66. Collani, S.; Neumann, M.; Yant, L.; Schmid, M. FT Modulates Genome-Wide DNA-Binding of the bZIP Transcription Factor FD. Plant. Physiol. 2019, 180, 367-380. [CrossRef] [PubMed]

67. Soares, J.M.; Weber, K.C.; Qiu, W.; Stanton, D.; Mahmoud, L.M.; Wu, H.; Huyck, P.; Zale, J.; Jasim, K.A.; Grosser, J.W.; et al. The vascular targeted citrus FLOWERING LOCUS T3 gene promotes non-inductive early flowering in transgenic Carrizo rootstocks and grafted juvenile scions. Sci. Rep. 2020, 10, 1-18. [CrossRef] [PubMed] 